\title{
An Unusual Presentation of Mesiodens Tooth with Talon Cusp-Report of Four Cases and Literature Review
}

\author{
N.B. Nagaveni ${ }^{1}$, Rohan Shah ${ }^{2}$, Poornima $\mathrm{P}^{3}$ and Roshan N.M ${ }^{4}$ \\ Department of Pedodontics and Preventive Dentistry, College of Dental Sciences, Davangere, \\ Karnataka, India \\ Correspondence should be addressed to: Dr. Nagaveni N.B; nagavenianurag@gmail.com; \\ Received date: 19 November 2013; Accepted date: 10 January 2014; Published date: 23 April 2014 \\ Academic Editor: Ildiko Tarján \\ Copyright (c 2014. N.B. Nagaveni, Rohan Shah, Poornima P and Roshan N.M. Distributed under Creative \\ Commons CC-BY 3.0

\begin{abstract}
Mesiodens is an extra tooth most frequently seen in the maxillary anterior region. It occurs in different forms as conical, tuberculate, molariform or multi-lobed. The development of supernumerary tooth itself is a developmental anomaly of tooth number. Although its occurrence is the most observed clinical entity, supernumerary containing another anomaly is an interesting incident. Herewith, we present such four cases of supernumerary tooth containing anomaly of tooth shape i.e., dens evaginatus or talon cusp on facial surface which clinicians can encounter very rarely. A brief review of literature pertaining to this anomaly of rare combination is also reported.
\end{abstract}

Keywords: conical mesiodens; facial talon; supernumerary tooth; talon cusp.

\section{Introduction}

Talon cusp is an uncommon developmental anomaly of the tooth shape, characterized by an accessory cusp-like structure, projecting from the cingulum area or cemento-enamel junction of the maxillary or mandibular anterior teeth (Hattab et al., 1995). It is observed more frequently among males than females, and it occurs either unilaterally or bilaterally (de Saousa et al., 1999). There are insufficient epidemiological data regarding the true prevalence of this dental abnormality, and the frequency may vary with age, race and criteria used to define this anomaly (Buanviaje and Rapp 1984, Sedano et al., 1989, Chen and Chen 1986, Chawla et al., 1983).

Talon cusp has been reported more frequently in permanent maxillary incisors (Chawla et al., 1983, Davis and Brook 1985). However, there have been reports of talon cusps on permanent mandibular incisors

Cite this Article as: N.B. Nagaveni, Rohan Shah, Poornima P and Roshan N.M (2014), "An Unusual Presentation of Mesiodens Tooth with Talon Cusp - Report of Four Cases and Literature Review", Journal of Research and Practice in Dentistry, Vol. 2014 (2014), Article ID 183691, DOI: 10.5171/2014.183691 
(Mader 1981), and primary maxillary incisors (Chen and Chen 1986, Henderson 1977). Occurrence of talon cusp in supernumerary teeth is a rare dental phenomenon, and there have been few reported cases of talon cusp occurring on facial surface (Topaloglu et al 2008, Siraci et al 2006). The purpose of this article is to present four Indian patients with talon cusps which developed on the facial surface of the mesiodens in the maxillary arch.

\section{Case Reports}

Intra oral examination in three Indian patients, who reported to outpatient
Department of Pedodontics and Preventive Dentistry, exhibited talon cusp on the facial surface of mesiodens (Fig. 1, 2, 3 and 4). The affected patients included two girls and two boys aged between 5 years to 13 years. All four patients were in good general health. The first patient had complete permanent dentition; the second and third patient exhibited mixed dentition; and the fourth patient showed primary dentition. The detailed description of these patients associated with mesiodens tooth and talon cusps is presented in Table 1.
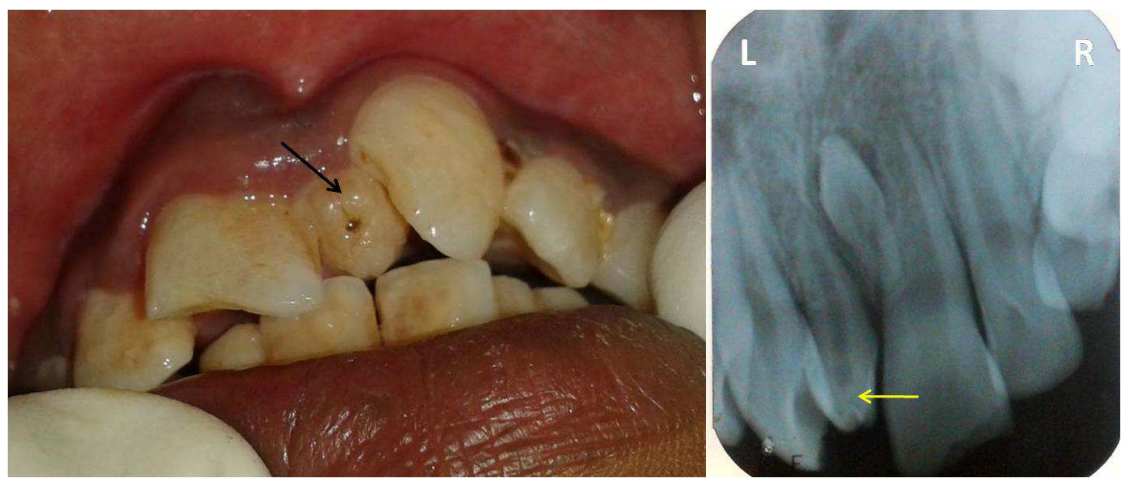

Figure1: Photograph and radiograph showing talon cusp in mesiodens (arrows)

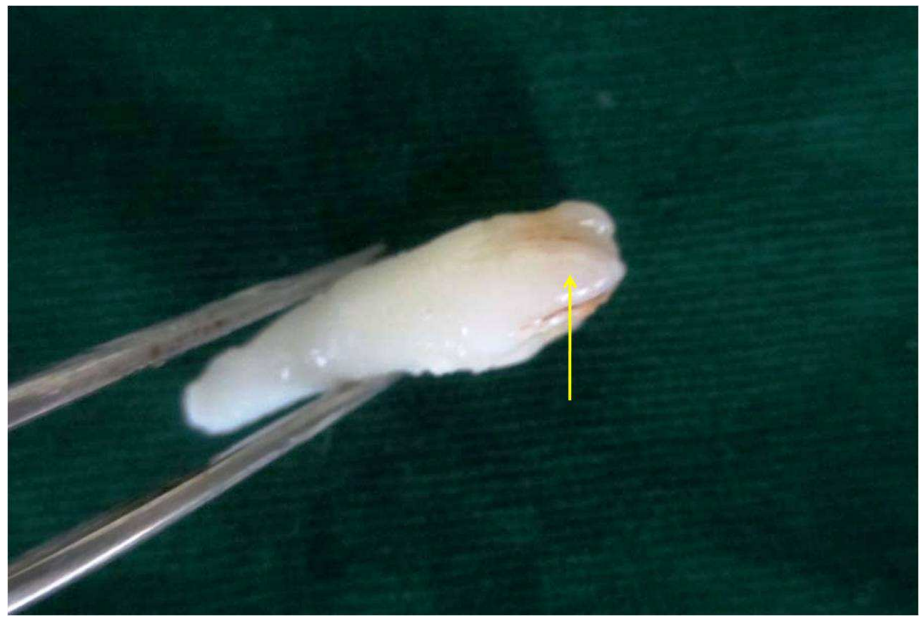

Figure2: Extracted mesiodens showing facial talon cusp (arrow)

N.B. Nagaveni, Rohan Shah, Poornima P and Roshan N.M (2014), Journal of Research and Practice in Dentistry, DOI: $10.5171 / 2014.183691$ 


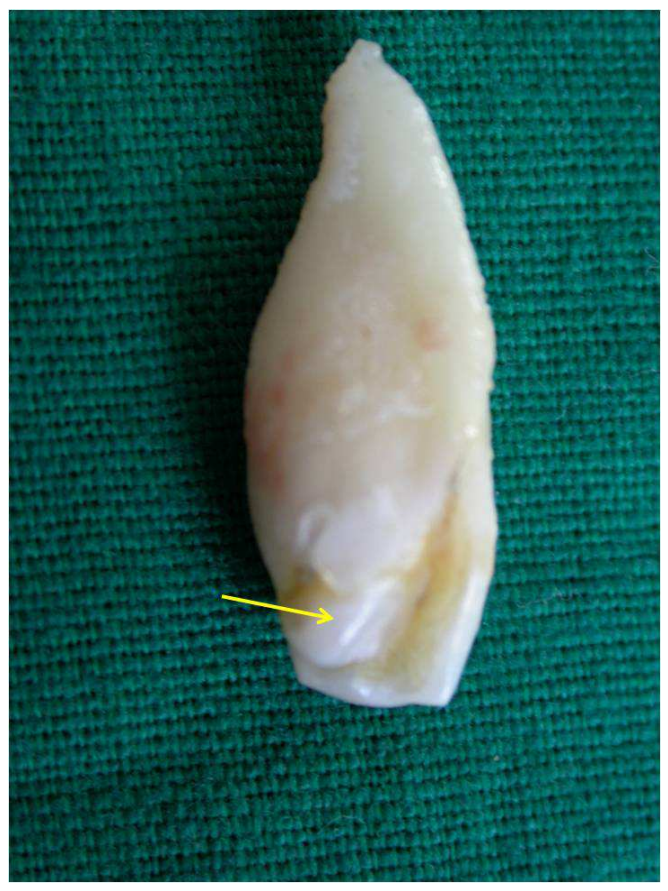

Figure 3: Extracted permanent mesiodens with talon cusp (arrow)

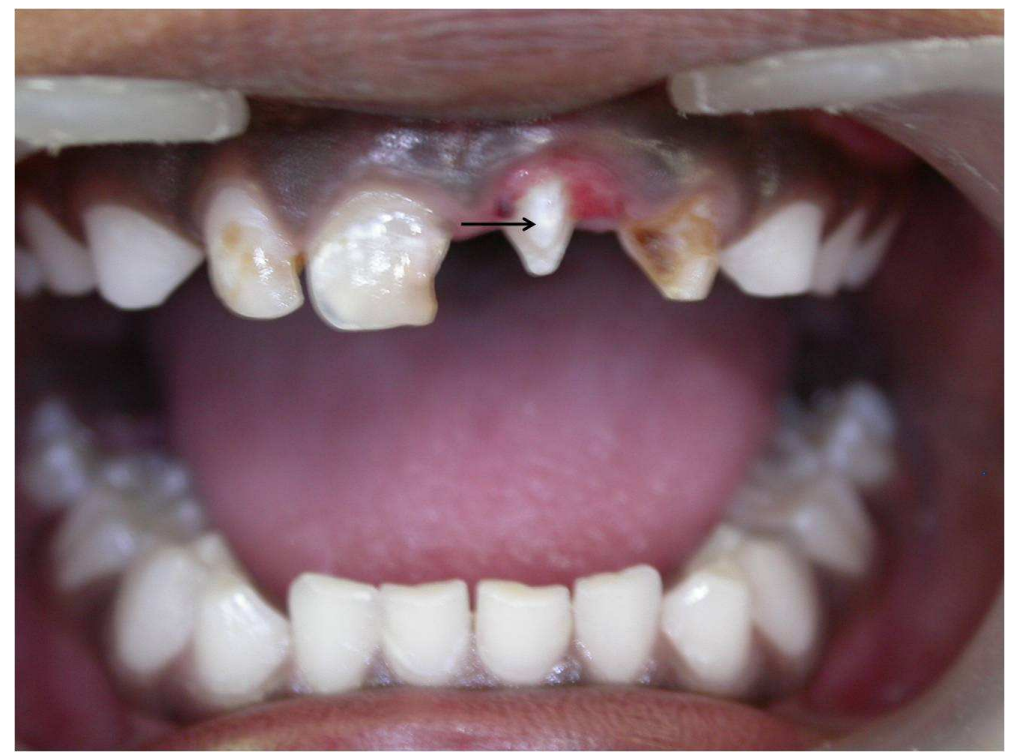

Figure4: Supernumerary primary tooth with facial talon (arrow)

N.B. Nagaveni, Rohan Shah, Poornima P and Roshan N.M (2014), Journal of Research and Practice in Dentistry, DOI: $10.5171 / 2014.183691$ 
Table1. Description of four cases of mesiodens with talon cusp

\begin{tabular}{|c|c|c|c|c|c|c|}
\hline $\begin{array}{l}\text { Case } \\
\text { no. }\end{array}$ & $\begin{array}{l}\text { Age \& } \\
\text { gender }\end{array}$ & $\begin{array}{l}\text { Supernume } \\
\text { rary type \& } \\
\text { shape }\end{array}$ & $\begin{array}{l}\text { Talon } \\
\text { cusp } \\
\text { type }\end{array}$ & $\begin{array}{l}\text { Talon } \\
\text { cusp } \\
\text { locatio } \\
\text { n }\end{array}$ & $\begin{array}{l}\text { Associated clinical } \\
\text { problems }\end{array}$ & Treatment advised \\
\hline $\begin{array}{l}1 . \\
\text { (Fig. 1) }\end{array}$ & $\begin{array}{l}14 \text { years, } \\
\text { Boy }\end{array}$ & $\begin{array}{l}\text { Permanent } \\
\text { Conical }\end{array}$ & Type 3 & Facial & $\begin{array}{l}\text { Occlusal interference, } \\
\text { unaesthetic appearance }\end{array}$ & $\begin{array}{l}\text { Extraction+orthodo } \\
\text { ntic management }\end{array}$ \\
\hline $\begin{array}{l}2 . \\
\text { (Fig. 2) }\end{array}$ & $\begin{array}{l}10 \text { years, } \\
\text { Girl, }\end{array}$ & $\begin{array}{l}\text { Permanent } \\
\text { Conical }\end{array}$ & Type 1 & Facial & $\begin{array}{l}\text { Occlusal interference, } \\
\text { Crowding, unaesthetic } \\
\text { appearance }\end{array}$ & $\begin{array}{l}\text { Extraction+orthodo } \\
\text { ntic management }\end{array}$ \\
\hline $\begin{array}{l}3 . \\
\text { (Fig. 3) }\end{array}$ & $\begin{array}{l}11 \text { years, } \\
\text { Boy }\end{array}$ & $\begin{array}{l}\text { Permanent } \\
\text { Conical }\end{array}$ & Type 1 & Facial & $\begin{array}{l}\text { Occlusal interference, } \\
\text { Crowding, unaesthetic } \\
\text { appearance }\end{array}$ & $\begin{array}{l}\text { Extraction+orthodo } \\
\text { ntic treatment }\end{array}$ \\
\hline $\begin{array}{l}4 . \\
\text { (Fig. 4) }\end{array}$ & $\begin{array}{l}5 \text { years, } \\
\text { Girl }\end{array}$ & $\begin{array}{l}\text { Primary } \\
\text { Conical }\end{array}$ & Type 1 & Facial & $\begin{array}{l}\text { Spacing, unaesthetic } \\
\text { appearance }\end{array}$ & Extraction \\
\hline
\end{tabular}

\section{Discussion}

The occurrence of both supernumerary and dens evaginatus is an interesting dental anomaly with which every clinician should have knowledge for an accurate diagnosis and a correct treatment. The exact cause behind the development of both supernumerary tooth and talon cusp is not clearly stated. It is attributed to the hyper production of the dental components from the dental lamina that is more common in the maxillary anterior region (Salama et al 1990). Previous published literature suggests that $75 \%$ of the talon cusps have been found in permanent incisors (lateral incisors followed by central incisors and canines), and the occurrence of talon in supernumerary tooth like mesiodens is an uncommon finding. According to literature search till date, only twelve cases of talon cusp occurring in supernumerary tooth have been reported (Table 2) (Hattab et al 1996, Salama et al 1990 (two cases), Zhu et al 1997,
Nadkarni et al 2002, Topaloglu et al 2008, Siraci et al 2006, , Nagaveni et al 2010, Babaji et al 2010, Nagaveni et al 2010, Rani et al 2010, Nuvvula et al 2011). Among these, nine cases occurred in permanent supernumerary tooth (Salama et al 1990, Hattab et al 1996, Zhu et al 1997, Nadkarni et al 2002, Nagaveni et al 2010, Babaji et al 2010, Nagaveni et al 2010, Rani et al 2010, Nuvvula et al 2011), and three cases (Topaloglu et al 2008, Siraci et al 2006, Salama et al 1990) in the primary mesiodens teeth. In all nine cases, talon affected the palatal surface (Salama et al 1990, Hattab et al 1996, Zhu et al 1997, Nadakarni et al 2002, Nagaveni et al 2010, Babaji et al 2010, Rani et al 2010, Nuvvula et al 2011), in one case, talon found on facial surface (Nagaveni et al 2010 ) and in two cases (Topaloglu et al 2008, Siraci et al 2006), talon occurred on both palatal and facial surfaces. In this report, three cases of talon cusp were associated with permanent mesiodens, and one case with primary mesiodens tooth. 
Table 2: Reported cases of talon cusp in mesiodens tooth

\begin{tabular}{|c|c|c|c|}
\hline Author and year & Mesiodens type and shape & $\begin{array}{l}\text { Location of talon } \\
\text { cusp }\end{array}$ & $\begin{array}{l}\text { Talon } \\
\text { cusp } \\
\text { type }\end{array}$ \\
\hline 1. Hattab et al (1996) & Permanent, Conical & Palatal & Type 1 \\
\hline 2. Salama et al (1990) & $\begin{array}{ll}\text { 1. } & \text { Primary, conical } \\
\text { 2. } & \text { Permanent, conical }\end{array}$ & $\begin{array}{l}\text { Palatal } \\
\text { Palatal }\end{array}$ & $\begin{array}{l}\text { Type } 3 \\
\text { Type } 3\end{array}$ \\
\hline 3. Zhu et al (1997) & Permanent, conical & Palatal & Type 3 \\
\hline 4. Nadkarni et al (2002) & Permanent, conical & Palatal & Type 3 \\
\hline 5. Topaloglu et al (2008) & Primary, conical & Facial and palatal & Type 1 \\
\hline 6. Siraci et al (2006) & Primary, conical & Facial and palatal & Type 2 \\
\hline 7. Nagaveni et al (2010) & Permanent, Multi-lobed & Palatal & Type 1 \\
\hline $\begin{array}{ll}8 . & \text { Babaji et al (2010) }\end{array}$ & Permanent, conical & Palatal & Type 1 \\
\hline 9. Nagaveni et al (2010) & Permanent, conical & Facial & Type 1 \\
\hline 10. Rani et al (2010) & $\begin{array}{l}\text { Permanent, conical, fused with } \\
\text { lateral incisor }\end{array}$ & Palatal & Type 1 \\
\hline 11. Nuvvula et al (2011) & Permanent, Supplemental & Palatal & Type 3 \\
\hline
\end{tabular}

The majority of times, talon cusp is seen on lingual surface of anterior teeth. Literature documentation of facial talons in a supernumerary tooth is very few and little or no epidemiological information is available. Extensive literature search revealed only three publications of facial talon in supernumerary tooth (Siraci et al 2006, Topaloglu et al 2008, Nagaveni et al 2010). One publication is by Siraci et al (2006), who reported both facial and palatal talons on a supernumerary primary incisor with pulp extensions detected by a micro-CT. Another case is reported by Topaloglu et al (2008), who also found both facial and palatal talons in primary mesiodens. Recently Nagaveni et al (2010) in their epidemiological survey of mesiodens occurring in 2500 Davangere (India) children reported a case of facial talon in maxillary mesiodens tooth. Therefore, the development of talon on the facial aspect of a supernumerary tooth further constitutes a rarer entity. In all our cases, talon cusps were found on the facial surface of mesiodens teeth thereby being an extremely rare occurrence.

Jowharji et al (1992) commented on facial talon anomaly and suggested that an alteration to the conventional definition of talon cusps be made; taking into consideration that talon cusp may be found on the facial aspect of teeth. However, they (Jowharji et al 1992) limited the definition to incisor teeth. Later McNamara et al (1997) reported a facial talon on maxillary canine tooth in 1997, and suggested that the definition should include teeth in addition to 
the incisor group and be extended to include the facial aspect too. According to these authors' opinion and from our cases, we strongly recommend, for a better understanding of this condition, that the definition should be further extended to include the mesiodens tooth.

Hattab et al (1996) have classified the talon cusps into three types based on the degree of formation and extension. Type 1 talon refers to a morphologically well-delineated additional cusp that prominently projects from the palatal surface of a primary or permanent anterior tooth, and extends at least half the distance from the CEJ to the incisal edge. Type 2 talon is an additional cusp of a millimeter or more, extending less than half the distance from the CEJ to the incisal edge. It may blend with the palatal surface or stand away from the rest of the crown. And type 3 is enlarged or prominent cingula and their variations, i.e., conical, bifid, or tubercle like. The same classification can be employed in classifying the facial talon cusps too. Therefore, based on this classification, our reported cases were categorized as type 3 Talon cusp in first case as the talon appeared like a small tubercle. In second, third and fourth case, the talon extended more than half distance from the CEJ to the incisal edge. Hence they were classified as type 1 talon. .

Supernumerary teeth in the primary dentition are usually normal or conical in shape. In the permanent dentition, they show great variation in morphology. Primosch (1981) classified them into supplemental or eumorphic and rudimentary or dysmorphic types (conical, tuberculate and molariform), according to their shapes. According to Koch et al in (1986), supernumerary teeth may be classified as $56 \%$ conical, $12 \%$ tuberculate, $11 \%$ supplemental, and $12 \%$ other configurations. Recently, Nagaveni et al (2010) presented a new form of mesiodens (multi-lobed mesiodens) associated with a palatal talon. In the presented four cases, the mesiodens tooth was classified as conical type based on the above classification.
Treatment modality for talon cusps may differ depending on each case and presenting complaints (Hattab et al 1996). In this report, extraction of involved tooth was advised in all three cases, as the affected teeth were a mesiodens which caused occlusal interference and esthetic problems followed by orthodontic treatment.

\section{References}

1. Babaji P, Sanadi F, and Melkundi M. (2010) "Unusual case of a talon cusp on a supernumerary tooth in association with a mesiodens," Journal of Dental Research Dental Clinics Dental Prospects, 4(2):60-3.

2. Buanviaje T. M, and Rapp R. (1984) "Dental anomalies in children: A clinical and radiographic survey," Journal of Dentistry for Children, 51:42-6.

3. Chawla H. S, Tewari A, and Gopalakrishnan N. S. (1983) "Talon cusp - a prevalence study," Journal of Indian Society of Pedodontics and Preventive Dentistry, 28-34.

4. Chen R. J, and Chen H. S. (1986) "Talon cusp in primary dentition," Oral Surgery, Oral Medine Oral Pathology Oral Radiology Endodontics, 62: 67-72.

5. Davis P. J, and Brook A. J. (1985) "The presentation of talon cusp: Diagnosis, clinical features, associations and possible etiology," British Dental Journal, 159: 84-88.

6. de Saousa S. M. G, Tavano S. M. R, and Bramante C. M. (1999) "Unusual case of bilateral talon cusp associated with dens invaginatus," International Endodontic Journal, 32: 494-8.

7. Hattab F. N, Yassin O. M, and Al-Nimri K. S. (1990) "Talon cusp in permanent dentition associated with other dental anomalies: Review of literature and report of seven cases," Journal of Dentistry for Children, 63: 368-76.

8. Hattab F. N, Yassin O. M, and Al-Nimri K. S. (1995) "Talon cusp - clinical significance and 
management: case reports," Quintessence International, 26:115-20.

9. Henderson H. Z. (1977) "Talon cusp: a primary or permanent dentition anomaly," Journal of Indian Dental Association, 56: 4556.

10. Jowharji N, Noonan R. G, and Tylka J. A. (1992) "An unusual case of dental anomaly: A facial talon cusp," ASDC J Dent Child , 59(2): 156-158.

11. Koch H, Schwartz O, and Klausen B. (1986)"Indications for surgical removal of supernumerary teeth in the premaxilla," International Journal of Maxillofacial Surgery, 15: 273-281.

12. Mader C. L. (1981) "Mandibular talon cusp," Journal of American Dental Association, 103: 244-246.

13. McNamara T, Haeussler A, and Keane J. (1997) "Facial talon cusps," International Journal of Pediatric Dentisty, 7: 259-262.

14. Nadkarni U. M, Munshi A, and Damle S. G. (2002) "Unusual presentation of talon cusp: two case reports," International Journal of Pediatric Dentistry, 12: 332-335.

15. Nagaveni N. B, Umashankara K. V, Sreedevi, Reddy B. P, Radhika N. B, and Satisha T. S. (2010) "Multi-lobed mesiodens with a palatal talon cusp - A rare case report," Brazilian Dental Journal, 21(4): 375378.

16. Nagaveni NB, Sreedevi B, Praveen BS, Praveen Reddy B, Vidyullatha BG, and Umashankara KV. (2010) "Survey of mesiodens and its characteristics in 2500 children of Davangere city, India," European Journal of Paediatric Dentistry, 11(4): 185188.

17. Nuvvula $S$, Pavuluri C, Mohapatra A, and Nirmala S.V. (2011) "Atypical presentation of bilateral supplemental maxillary central incisors with unusual talon cusp," Journal of Indian Society of Pedodontics and Preventive Dentistry," 29(2):149-54.

18. Primosch R. E. (1981) "Anterior supernumerary teeth. Assessment and surgical intervention in children," Pediatric Dentistty, 3: 204-215.

19. Rani A. K, Metgud S, Yakub S. S, Pai U, Toshniwal N. G, and Bawaskar N. (2010) "Endodontic and esthetic management of maxillary lateral incisor fused to a supernumerary tooth associated with a talon cusp by using spiral computed tomography as a diagnostic aid: a case report," Journal of Endodontics, 36: 345-349.

20. Salama F. S, Hanes C. M, Hanes P. J, and Ready M. A. (1990) "Talon cusp: a review and two case reports on supernumerary primary and permanent teeth," Journal of Dentistry for Children, 57: 147-149.

21. Sedano H. O, Freyre I. C, and de La Garza M. L. (1989) "Clinical orodental abnormalities in Mexican children," Oral Surgery Oral Medicine Oral Pathology Oral Radiology Endodontics, 68:300-11.

22. Siraci E, Gungor H. C, Taner B, and Cehreli Z. C. (2006) "Buccal and palatal talon cusps with pulp extensions on a supernumerary primary tooth," Dentomaxillofacial Radiology, 35: 469-472.

23. Topaloglu A. K A, Eden E, Ertugrul F, and Sutekin E. (2008) "Supernumerary primary tooth with facial and palatal talon cusps: A case report," Journal of Dentistry for Children, 75: 309-312.

24. Zhu J. F, King D. L, and Henry R. J (1997). "Talon cusp associated with adjacent supernumerary tooth," General Dentistry, 45(2):178-81. 